\title{
Effect of the Pressure applied to the Acid-etched Enamel on the Adhesive Strength of the Bonding Agent
}

\author{
Kazuomi SUZUKI*, Tadashi MUNECHIKA**, Jiro TANAKA*, Masao IRIE* and \\ Hiroyuki NAKAI* \\ *Department of Dental Materials, Okayama University Dental School, Okayama 700, Japan \\ **Department of Dental Materials, Nihon University School of Dentistry, Kanda-Surugadai, Tokyo 101, \\ Japan
}

Received on March 10, 1986

Acid-etched enamel can be damaged by careless instrumentation during the application of bonding agents. In such a case, the adhesive strength of the resultant bonding agent may be impaired to a considerable degree, resulting in an unfavorable marginal integrity. The effects of applied pressure to the acid-etched enamel on the adhesive strength of the bonding agent were examined microstructurally. The influence of pressure was marked. For example, when a sponge pellet was used to apply the pressure, an adhesive strength of ca. $190 \mathrm{~kg} / \mathrm{cm}^{2}$ resulted following the applied pressure of $0.01-0.03 \mathrm{~g}$. However, it decreased to ca, 100 and $50 \mathrm{~kg} / \mathrm{cm}^{2}$ when the applied pressure was $2-3 \mathrm{~g}$ and $7-10 \mathrm{~g}$, respectively. Therefore, the bonding agent should be applied as carefully as possible.

Key words: Acid-etched enamel, Destruction, Bonding strength

\section{INTRODUCTION}

The acid-etching of enamel and subsequent application of a bonding agent are necessary procedures for the adhesion of restorations and appliances. Many investigations have been made on the acid-etching technique ${ }^{1,2}$, and it is now commonly used in clinical practice. However, even when acid-etching has made the enamel surface favourable for adhesion, factors inhibiting adhesion do exist ${ }^{3-5)}$, such as residual moisture of the etching solution, saliva, expiration, and destruction of the acid-etched enamel during the restorative procedure.

Previously we reported ${ }^{6,7)}$ that the destruction of the acid-etched enamel following the accidental contact of the instrument during the application of a bonding agent decreases the adhesive strength of the agent. However, in these studies, the pressure was not estimated quantitatively. In this study, we estimated preliminary the pressure produced following the application of the bonding agent. Pressure was then applied to the acid-etched enamel, and the relationship between applied pressure and the adhesive strength of the bonding agent was examined. The effect of the instruments, such as sponge pellet, brush, cotton pellet, was examined morphologically and mechanically. The microleakage between the bonding agent and acid-etched enamel was also examined.

\section{MATERIALS AND METHODS}

1. Preparation of specimens

The labial surface of freshly extracted human permanent central incisor, stored in 
distilled water, was flattened wich sand paper (JIS \# 600) and mounted in self-curing acrylic resin. Exposed enamel was etched with a $40 \%$ aqueous solution of phosphoric acid, rinsed with water and dried. It was fixed to the table to an electronic balance with tacking tape. The instrument used for appling the bonding agent was fixed to the travelling stage of a microhardness tester. The tip of the instrument was put in contact with the acid-etched enamel and moved horizontally at a speed of $20 \mathrm{~mm} / \mathrm{min}$. This procedure was repeated by maintaining the distance of $0.5 \mathrm{~mm}$.

Figure 1 shows the pressure applied. With a sponge pellet (Kuraray, included in the package of Clearfil F-II), at a pressure of $0.01-0.03 \mathrm{~g}$, its original shape was maintained, at $0.2-0.6 \mathrm{~g}$, its height was reduced to approximately half, and at $8-12 \mathrm{~g}$ it was flattened. With a brush (Tokuyama Soda, included in the package of Palfique), the pressure was $0.2-0.3 \mathrm{~g}, 2$ $-4 \mathrm{~g}$ and 13-16 $\mathrm{g}$ when about 2,4 and $6 \mathrm{~mm}$ of its tip was in contact, respectively. The cotton pellet had a similar impact as the sponge pellet.



Fig. 1 Pressures applied to the acid-etched enamel by a sponge pellet (top), brush (middle) and cotton pellet (bottom).

In addition to the above-mentioned specimens which had cross-sectioned enamel, specimens having longitudinally sectioned enamel were made. A premolar was used to make the specimen, whose crown was ground bucco-lingually.

2. Determination of adhesive strength

A polyethylene ring, $3.2 \mathrm{~mm}$ in diameter inside, was fixed on the acid-etched enamel surface with double-sided tack tape. The bonding agent (Kuraray, Clearfil New Bond) was applied carefully by its own weight, and a composite resin was then applied. Ten minutes later, the ring was removed. The resultant specimen was stored in water at $37^{\circ} \mathrm{C}$ for 24 hours.

The adhesive strength was determined by a testing machine with a cross-head speed of $2 \mathrm{~mm} / \mathrm{min}$. The testing procedure was described in detail, elsewhere ${ }^{8)}$. In each experiment, 9-12 determinations were made. 


\section{Examination of marginal leakage}

A pressure of 7-13 $\mathrm{g}$ was applied to the acid-etched enamel with a cotton pellet, then, a thermal cycle ( 4 and $60^{\circ} \mathrm{C}$, maintained 1 minute, alternatively) was applied 400 times and stained with fuchsin. A scanning electron micrograph was made. An acid-etched enamel surface, to which a pressure of $0.01-0.03 \mathrm{~g}$ was applied by a sponge pellet, was used as a control.

\section{RESULTS AND DISCUSSION}

Figure 2 shows the adhesive strength of bonding agent to the acid-etched enamel, to which the pressure was applied with a sponge pellet.



Fig. 2 Adhesive strength of bonding agent to the cross-sectioned, acid-etched enamel to which pressure was applied by a sponge pellet.

Figure 3 shows the SEM observations of the enamel surface. In these cases, the cross-sectioned enamel was exposed, and the adhesive strength was $185 \mathrm{~kg} / \mathrm{cm}^{2}$ when the pressure of 0.01-0.03 $\mathrm{g}$ was applied, but, it decreased with the increase in the applied pressure and at $7-10 \mathrm{~g}$, the resultant adhesive strength decreased to as little as $50 \mathrm{~kg} / \mathrm{cm}^{2}$. As is apparent in Fig. 3, the etched enamel was damaged by the contact of the sponge pellet. Therefore, the greater the applied pressure, the more damaged the enamel thus showing smaller adhesive strength. The lack of an interlocking force following the insufficient formation of the resultant resin tag is apparent as shown in Fig. 4. As it is also apparent in 




$7.5 \mu \mathrm{m}$

$(0.01 \sim 0.03 \mathrm{~g})$

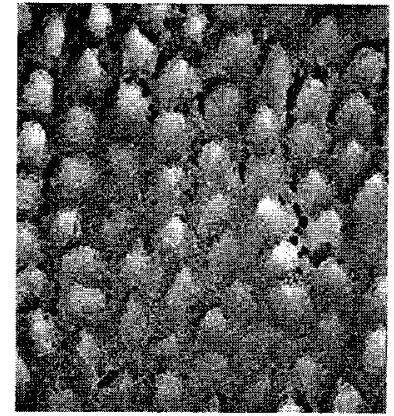

$7.5 \mu \mathrm{m}$

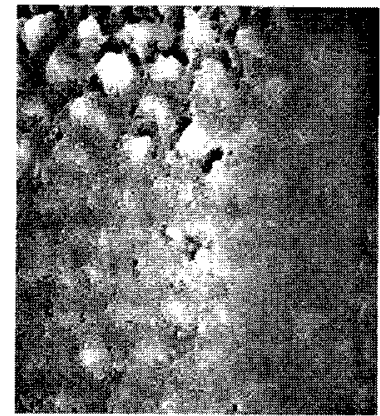

$7.5 \mu \mathrm{m}$



Fig. 3 SEM of enamel employed in Fig. 2.



$5 \mu \mathrm{m}$



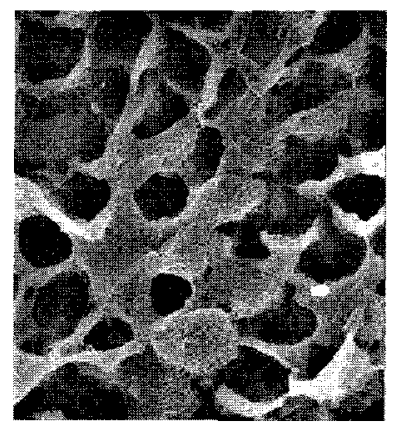

$5 \mu \mathrm{m}$



$5 \mu \mathrm{m}$

\section{$(7-10 \mathrm{~g})$}

Fig. 4 SEM of bonding agent (resin tag) resulting from Fig. 3.

Figs. 3 and 4 , the acid-etched enamel was not damaged following the application of $0.01-0.03$ $\mathrm{g}$, indicating that the resultant resin tag is favourable for adhesion.

Figures 5, 6, 7 show the SEM observations on the adhesive strength of the bonding agent to the longitudinally sectioned acid-etched enamel. Adhesive strength of $110 \mathrm{~kg} / \mathrm{cm}^{2}$ is obtained following the pressure of $0.01-0.03 \mathrm{~g}$. It decreased with the increase in applied pressure, and with the pressure of 7-10 g, the adhesive strength was as little as $40 \mathrm{~kg} / \mathrm{cm}^{2}$. This tendency is similar to that of the above mentioned cross-sectional enamel. The adhesive strength was $20-40 \%$ lower than that of the cross-sectional enamel.

This is considered to be based upon the difference in mechanical properties and surface area of hydroxyapatite in acid-etched enamel, following its arrangement ${ }^{9 \text { ) }}$.

Figure 8 shows the adhesive strength of the bonding agent to the acid-etched crosssectioned enamel, to which pressure was applied with a brush. Figure 9 shows the SEM observations. Unlike the case of the sponge pellet, a bonding stregth of $60 \mathrm{~kg} / \mathrm{cm}^{2}$ was obtained following the large pressure of 13-16 $\mathrm{g}$, which is not so different from the case of a small pressure of $2-3 \mathrm{~g}$. This is considered to result from the reduction in the stress following 
the expansion of the brush (Fig. 1) by the application of such a large pressure. This is indicated by the SEM observation in Fig. 9.

Figure 10 shows adhesive strength of a bonding agent to the acid-etched enamel, to which pressure was applied with a cotton pellet. Figure 11 shows a SEM observation when a pressure of 7-10 $\mathrm{g}$ was applied. A similar tendency as with the sponge pellet and brush was observed. However, following the application of a small pressure $(0.01-0.03,0.2-0.6 \mathrm{~g})$, the resultant strength was $15-25 \%$ lower than that of the sponge pellet. This is also considered

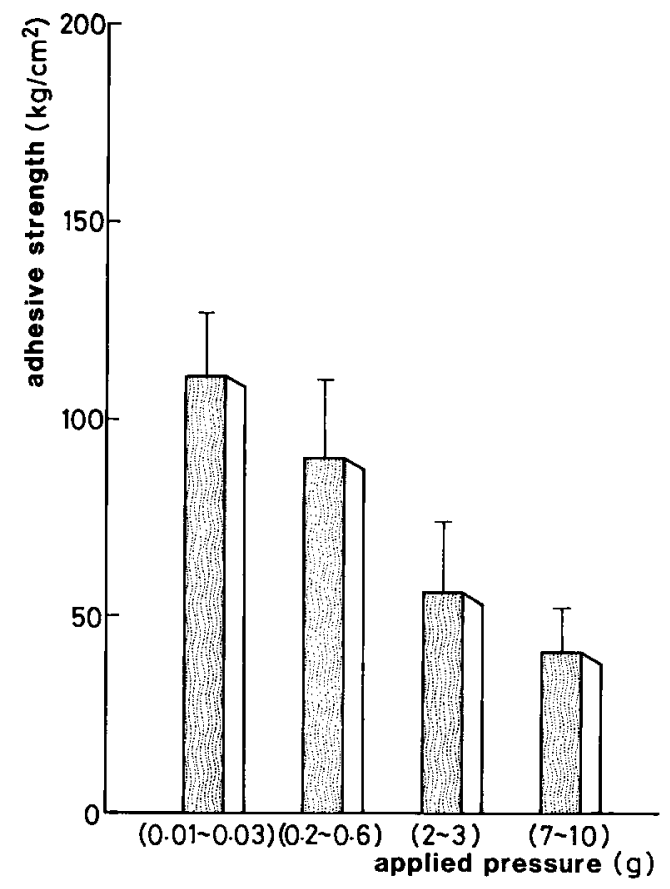

Fig. 5 Adhesive strength of bonding agent to the longitudinally sectioned, acidetched enamel to which pressure was applied by a sponge pellet.

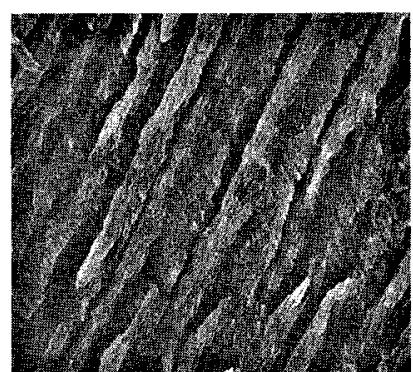

$7.5 \mu \mathrm{m}$



$7.5 \mu \mathrm{m}$

\section{$(0.01-0.03 \mathrm{~g}) \quad(7-10 \mathrm{~g})$}

Fig. 6 SEM of enamel employed in Fig. 5. 




$7.5 \mu \mathrm{m}$

$(0.01-0.03 \mathrm{~g})$

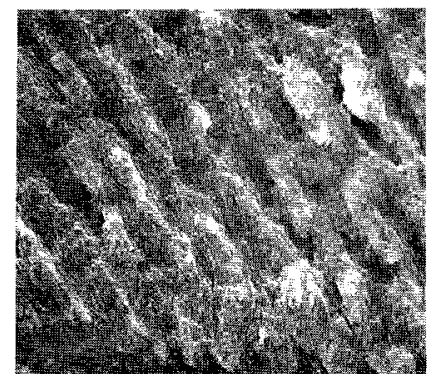

$7.5 \mu \mathrm{m}$

Fig. 7 SEM of bonding agent (resin tag) resulting from Fig. 6.

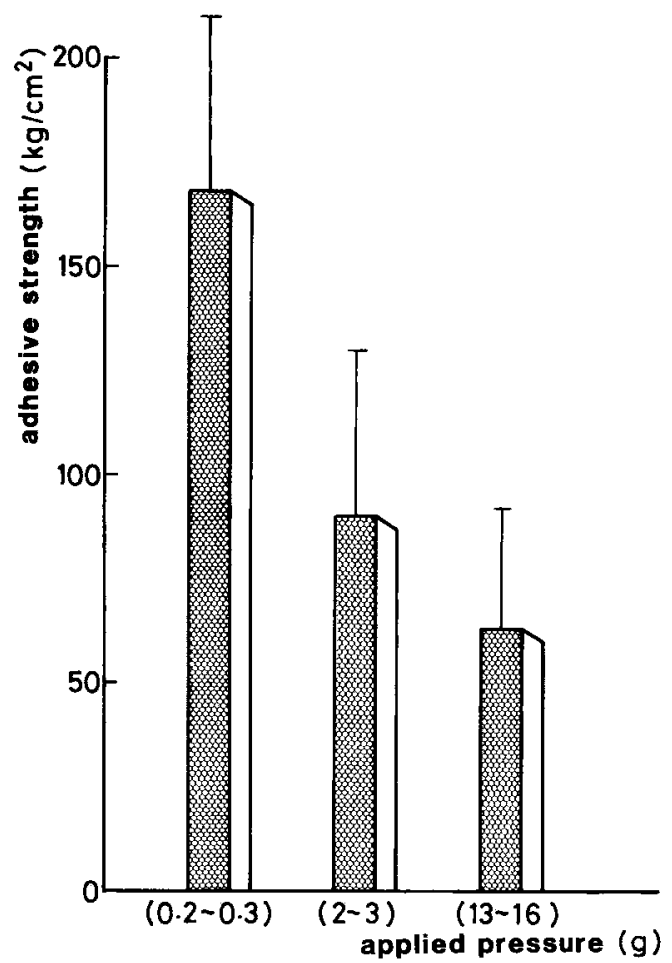

Fig. 8 Adhesive strength of bonding agent to the cross-sectioned, acid-etched enamel to which pressure was applied by a brush.

to result from the difference in the stress during pressure application. The scratches are considerably larger than those produced with a sponge pellet.

In the microleakage test, no penetration of dyes between the bonding agent and acidetched enamel was observed in the control (applied pressure is 0.01-0.03 g). However, the acid-etched enamel, to which a pressure of $7-13 \mathrm{~g}$ was applied, indicated penetration of the 


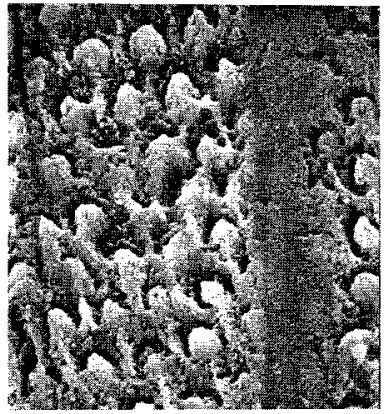

$7.5 \mu \mathrm{m}$

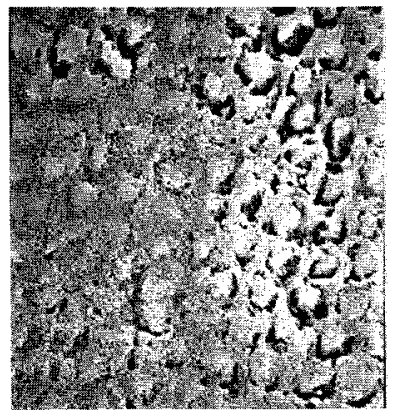

$7.5 \mu \mathrm{m}$

$(0.2 \sim 0.3 \mathrm{~g})$



$7.5 \mu \mathrm{m}$

Fig. 9 SEM of enamel employed in Fig. 8.

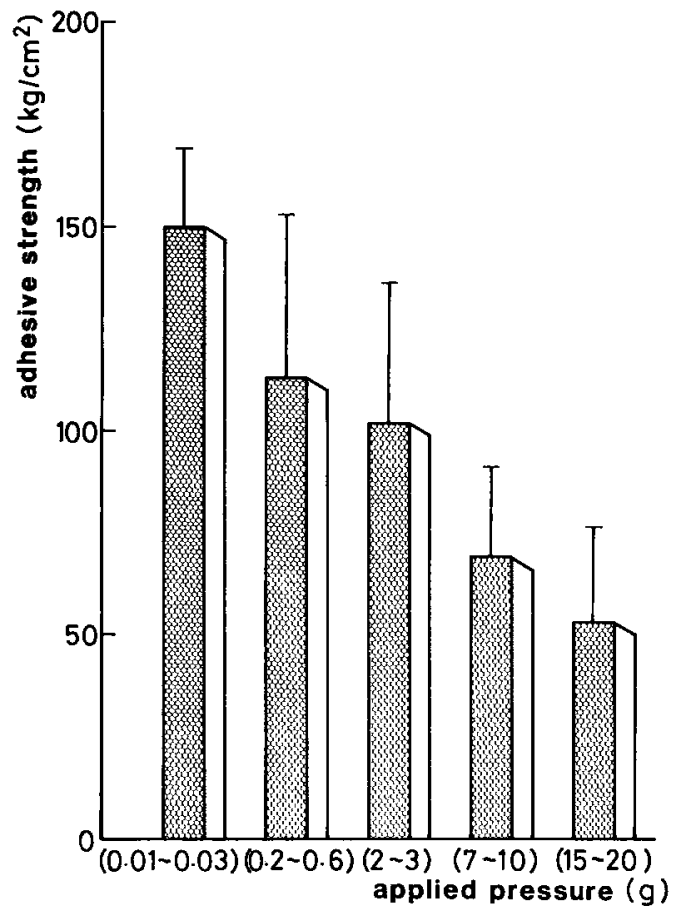

Fig. 10 Adhesive strength of bonding agent to the cross-sectioned, acid-etched enamel to which pressure was applied by a cotton pellet.

dyes, following microleakage. The SEM photograph in Fig. 12 show the interface between acid-etched enamel and bonding agent. When the applied pressure was small (0.01-0.02 g), the resin tag along the acid-etched enamel prism was regularly shaped. However, when a large pressure (7-13 g) was applied to the acid-etched enamel, the resultant resin tag was irregular in shape, indicating a lack of interlocking between acid-etched enamel and resin tag. 


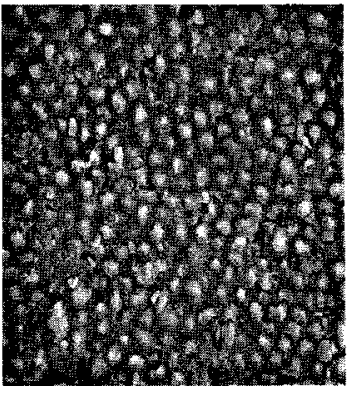

$14 \mu \mathrm{m}$

Fig. 11 SEM of enamel employed in Fig. 10 (pressure of 7-10 $\mathrm{g}$ was applied).

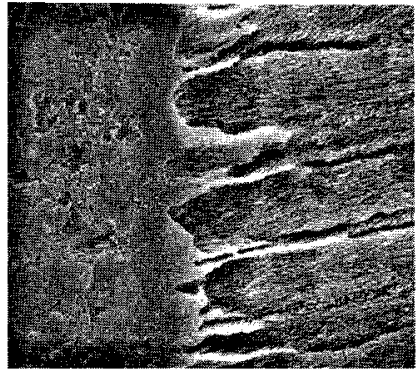

$6 \mu \mathrm{m}$

$(0.01-0.03 g)$

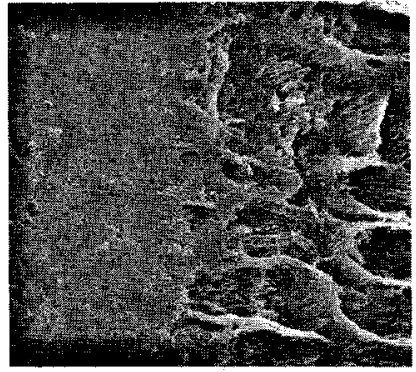

$6 \mu \mathrm{m}$

$(7-13 g)$

Fig. 12 SEM of the interface between acid-etched enamel and bonding agent (resin tag) after thermally cycled. Left, a small pressure $(0.01-0.03 \mathrm{~g}$, control) ; right, a large pressure (7-13 g) was applied.

Therefore, it is apparent that a pressure of only a few grams applied on the acid-etched enamel could impair the interlocking between bonding agent. This means that the strength of an acid-etched enamel is very small. Extreme care should be taken during the application of the bonding agent and adhesives. It is particularly important during the orthodontic and adhesive restorative procedures, because the surface of the acid-etched enamel is very large in these cases.

\section{CONCLUSION}

Various pressures were applied on the acid-etched enamel with several kind of instruments. The adhesive strength of the bonding agent to this surface was determined and a SEM observation was made. A microleakage test was also carried out. The following results were obtained :

1. The adhesive strength of the bonding agent was $185 \mathrm{~kg} / \mathrm{cm}^{2}$ when a pressure of $0.01-$ $0.03 \mathrm{~g}$ was applied by a sponge pellet. It decreased with an increase in the pressure, and at $7-10 \mathrm{~g}$, it became as small as $50 \mathrm{~kg} / \mathrm{cm}^{2}$. In the case of the longitudinally sectioned enamel, 
the adhesive strength was $20-40 \%$ smaller than that of the cross-sectioned.

2. When a brush or cotton pellet was used for the application of pressure, similar trends as described above were observed. Yet, the adhesive strength obtained was $15-25 \%$ smaller than that using a sponge or brush, when a small pressure of 0.01-0.6 $\mathrm{g}$ was applied, using a cotton pellet.

3. When a large pressure, such as 7-13 $\mathrm{g}$, was applied, microleakage occurred between the tooth structure and bonding agent.

4. An apparent relationship was observed between the microstructure of the acid-etched enamel and adhesive strength of the bonding agent.

\section{REFERENCES}

1) Buonocore, M. G. : A simple method of increasing the adhesion of acrylic filling materials to enamel surface, J Dent Res 34 (6) : 849-853, 1955.

2) Silverstone, L. M. and Dogon, I. L.: The acid etch technique, North Central Publishing Co., 1975, pp. 13-39, 70-73.

3) Soetopo, Beech, D. R. and Hardwick, J. L. : Mechanism of adhesion of polymers to acid-etched enamel, J Oral Rehabil 5 (1): 69-79, 1978.

4) Hormati, A. A., Fuller, J. L. and Denehy, G. E. : Effect of contamination and mechanical disturbance on the quality of acid-etched enamel, J Am Dent Assoc 100 (1) : 34-38, 1980.

5) Oppenheim, M. N. and Ward, G. T. : The restoration of fractured incisors using a pit and fissure sealant resin and composite material, J Am Dent Assoc 89 (2), 365-368, 1974.

6) Munechika, T., Suzuki, K. and Horie, K. : Studies on the adhesion of restorative material to the tooth substance (Part 1) Finestructural changes and adhesiveness of composite resin to the acid-etched enamel surface, J Japan Res Soc Dent Mat Appl 37 (2) : 200-216, 1980. (in Japanese)

7) Munechika, T., Suzuki, K., Yasuda, S. and Horie, K. : Studies on the adhesion of restorative material to the tooth substance (Part 2) Influence of the concentrations of phosphoric acid, etching times and the application methods of bonding agent to the adhesive strength of composite resin, J Japan Res Soc Dent Mat Appl 37 (4) : 392-403, 1981. (in Japanese)

8) Suzuki, K., Irie, M. and Nakai, H. : Studies on polymers adhesive to tooth structure (Part 3) Adhesiveness of methacrylate with $\alpha$-amino acid as a skelton, J Okayama Dent Soc 3 (1): 7-11, 1984. (in Japanese)

9) Munechika, T., Suzuki, K., Nishiyama, M., Ohashi, M. and Horie, K. : A comparison of the tensile bond strengths of composite resins to longitudinal and transverse sections of enamel prisms in human teeth, J Dent Res 63 (8), 1079-1082, 1984. 
をSEMにて観察した。引つ張り試験を終えた試料を観 察するとセメントは常にピンに付着しており，セメント とピンホールの界面にて剥離を生じていた。引つ張り試 験の結果，同じ直径のピンのグループでは保持面積が保 持力に比例したが，ピンの直径が異なるとそれに対応し
たピンホールの表面の粗さが異なり，そのために単位面 積あたりの保持力が違ってきて保持面積が同じでも保持 力が異なるという結果となった。

まとめ 1) 保持力は保持面積に比較する。

2）表面粗さが保持力に大きく影響する。

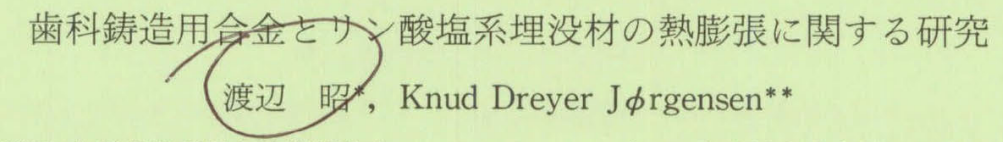

*昭和大学歯学部保存修復学教室＊*コペンハーゲン王立歯科大学歯科理工学教室

3 種の市販リン酸塩系埋没材の練和時間と練和液を変 えて, 円柱状試片を作り，示差熱膨張計にて室温より $900^{\circ} \mathrm{C}$ 迄の熱膨張を測定した。また 18 種の歯科鋳造用合 金をアルゴン雲囲気下にて融点より $100 \sim 250^{\circ} \mathrm{C}$ 低い温 度迄の熱膨張を測定し，合金の融点における熱膨張值を Grüneisenの公式にもとづいて推定した。埋没材は硬化 膨張が小さいと蠟型の変形を起こすことがないと言われ

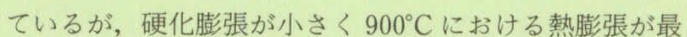
大であったのは, Platoritの $20 \%$ リセリン水溶液 60 秒練和の場合で, 熱膨張值は $1.31 \pm 0.02 \%$ \%うった埋 没材と合金の熱膨張を比較すると前者のみで後者を十分 に補償することができないのは明らかである。どの埋没 材も硬化膨張を小さく抑えた場合, 今回の練和条件下で は鋳造体は小さくなるものと思われる。

\section{構成元素の溶出量から検討したアマルガムの腐食}

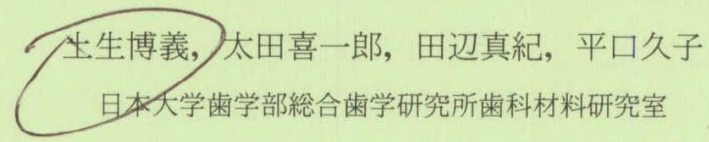

一般型及び高銅型アマルガム構成元素の溶出量を測定

し, $\gamma_{1}$ 相， $\gamma_{2}$ 相， $\eta$ 相の腐食比を求めた。

両アマルガムから溶出した銀に対する水銀量は， $\gamma_{1}$ 相 の比よりも小さかった。また，一般型アマルガムからは 多量の錫が溶出したが， $\gamma_{2}$ 相として対応するはずの水銀 が全く検出されなかった。一方高銅型アマルガムからは, $\eta$ 相の比で銅と錫が溶出した。また腐食の要因は, $\gamma_{1}$ 相に とって時間と温度が, $\gamma_{2}$ 相には溶液と時間が, $\eta^{\prime}$ 相には全 てが有意であった。

そして腐食後の微小組織の観察から, 両アマルガムに よる修復物の辺縁破折の機構の違いが示唆された。

酸エッチングエナメル質に加えられた圧が,

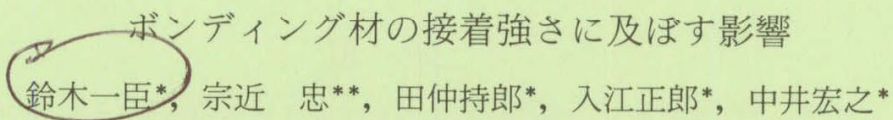

*岡山大学歯学部歯科理工学講座

ボンディング材を施す際の不注意によつて酸エッチン グされたエナメル質の破壊がおこることは充分予想され る。このような場合には接着強さが著しく低下し，辺縁 部の性状が劣化する可能性が大きい。本研究においては, 酸エッチングされたエナメル質に加えられた圧がボン
**日本大学歯学部歯科理工学教室

ディング材の接着強さに及ぼす影響を機械的性質と微細 構造の両面から検討した。圧の影響は非常に大きく，ス ポンジペレットを用いた場合, $0.01 〜 0.03 \mathrm{~g}$ の微少な压 では約 $190 \mathrm{~kg} / \mathrm{cm}^{2}$ の接着強さが得られたが, 圧が 2 〜 $3 \mathrm{~g}, 7 \sim 10 \mathrm{~g}$ と増大するに従って, それぞれ $100 \mathrm{~kg} /$ 
$\mathrm{cm}^{2}, 50 \mathrm{~kg} / \mathrm{cm}^{2}$ と著明に低下した。これらの事実から， 酸エッチングされたエナメル質にボンディング材を施す
際には出来る限り慎重におこなうべきであることが確認 された。

\section{接着性レジンと合金の接着機構の解明に関する研究}

—ESCA によって解析された Co-Cr 合金の表面構造とレジンの接着強さの関係

70 mass \%Co-30\%Cr 合金の 3 つの畧なる昰面状態

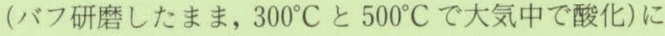
対する接着性レジン（4-META 添加）の接着性について 検討した。合金の表面構造は ESCA と反射電子回析で解 析し, 接着性と表面構造の関係について接着モデルを仮 定して論じた。

接着性は, 研磨したままの方が $300^{\circ} \mathrm{C}$ と $500^{\circ} \mathrm{C}$ で酸化 したものより優れていた。この接着性の優劣は, 液体チッ 素を用いた熱サイクルを施すことによって見出された。
研磨したままの表面構造は，20～30 §の非晶質の不働 態被膜で, $\mathrm{Cr}^{3+}$ や $\mathrm{Co}^{2+}$ または $\mathrm{Co}^{3+}$ を中心して $-\mathrm{OH}$ や $\mathrm{H}_{2} \mathrm{O}$ が 6 配位で結合していると考えられた。また， $300^{\circ} \mathrm{C}$ の場合は, $120 \AA$ の酸化被膜が形成され, その表層 は，主に $\mathrm{Co}_{3} \mathrm{O}_{4}$ から成っている。酸化層の表面には数分 子の $\mathrm{H}_{2} \mathrm{O}$ が吸着していると考えられ,この吸着水の存在 が，研磨したままの表面よりも接着性を低下させた原因 と考えられた。

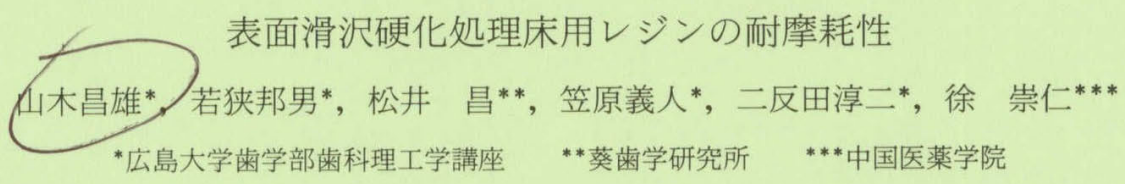

本研究では，表面滑沢硬化処理した床用レジンの耐摩 耗性を表面粗さ $\mathrm{R}_{\max }, \mathrm{R}_{\mathrm{z}}, \mathrm{R}_{\mathrm{a}}$ 及びブラシング消失量の観 点から検討した。すなわち, 表面滑沢硬化処理剂, Linkle Coat (Coating 1)及び Permacure Link (Coating 2)の 2 種類を用いて，それら処理したものと無処理のものとを
とを統計的に比較，検討した。その結果，表面滑沢硬化 処理した場合，その耐摩耗性は無処理のコントロールよ りもより優れており,とくに, Coating 1 による床用レジ ンの消失量は摩耗回数の増加にもかかわらず Coating 2 のものよりも少ないことが判明した。

\section{金属メッシュプレートの義歯床への応用 川傆春幸，石崎順啓，武田昭二，今井弘一，山形伸明 大阪歯科大学歯科理工学教室}

床義歯装着時におこりうる床下粘膜組織にみられる弊 害をできるだけ軽減し，粘膜の生理機能を自然状態に保 持できるような床用材料 TRUTISSU を試作し，いくつ かの基礎実験を行なうとともにモニターによる臨床観察 をも行ない, 以下のような評価を得た。1.TRUTISSU の成形性はよく，成形後の適合性は良好であった。 2 . 口蓋粘膜に対する床の吸接着維持については他の材料と
くらべて同等の維持力が示された。 3 . 生物学的適合性 についてはTRUTISSU の構成金属線上に対して良好 な細胞の接着ぬれを示し, 何らの変性も認められなかっ た。また， 口蓋粘膜をシミュレートした人工粘膜上の細 胞について TRUTISSU 直下の細胞は正常な増殖を示 した。4コバルト・クロム床やレジン床との比較につ いて，装着感，温度感および嗜好品に対する味覚などに 